\title{
Erros vernáculos mais freqüentemente cometidos no meio médico acadêmico Parte II
}

\author{
Carlos R.Souza-Dias
}

Por um equívoco deixou de sair no número anterior o verbete que segue:

Estágio. Com muita freqüência, tenho visto esta palavra mal empregada. Muitos colegas a usam quando deveriam dizer estádio. Estágio é o nome que se dá ao tempo em que se freqüenta um serviço para aprender alguma coisa (quase sempre, tenho colegas fazendo estágio na nossa Clínica da Sta. Casa, em alguma das suas Seções). Estágio é, também, o nome de cada uma das fases de um foguete espacial, que vão sendo ejetadas durante o vôo. Estádio, além do nome do campo para realização de jogos esportivos, significa fase, época, período. Portanto, as fases da evolução de uma doença são chamadas estádios. Aliás, é comum ver-se a palavra estadiamento (e não estagiamento), um neologismo relativo ao ato de dividir a evolução de uma doença em suas diferentes fases.

Nasal e temporal. Tenho visto, com enervante freqüência, colegas dizerem que operam o oblíquo superior por via nasal. Parece-me uma técnica cirúrgica inadequada e bastante difícil; é aconselhável pedir auxílio do oto-rino-laringologista. Por que não operar por via conjuntival, abordando o tendão por via medial ao reto superior ou, se se quer abreviar, apenas por via medial? Substituam-se as palavras nasal e temporal pelas mais corretas medial e lateral. Lembro-me de que antigamente se dizia reto interno e reto externo, bobagem semelhante a esta; felizmente, corrigiu-se o erro e, atualmente, todos dizem reto medial e reto lateral. Vale aqui comentar também outro erro semelhante, que é dizer-se que o olho dirigiu-se para dentro ou para fora, querendo-se dizer que o olho dirigiu-se medialmente ou lateralmente. Eu somente poderia entender que um olho dirigiu-se para dentro se ele entrasse órbita adentro ou, se se dirigiu para fora, luxou para fora da órbita.

Neologismos. Há certa tendência, atualmente, de criar neo-

Livre Docente pela Universidade de São Paulo - Escola Paulista de Medicina Professor Titular da Faculdade de Ciências Médicas da Santa Casa de São Paulo

Obras consultadas: Dicionário da Língua Portuguesa, Antenor Nascentes, Bloch Editores; Gramática Metódica da Língua Portuguesa, Napoleão Mendes de Almeida, Edição Saraiva; Dicionário de Questões Vernáculas, Napoleão Mendes de Almeida, Editora Caminho Suave; Dicionário Etimológico Nova Fronteira, Antonio Geraldo da Cunha; Utilidades Vernáculas ( $5^{\text {a }}$ edição), Antonio Giannella; Nomina Anatomica $5^{\mathrm{a}}$ edição, MEDSI, 1983. logismos. É claro que o progresso da ciência exige novas palavras, mas duas coisas devem ser observadas: 1) É preciso verificar se já não há uma palavra portuguesa que exprima o que se quer denominar; 2) A criação da nova palavra deve obedecer às normas do idioma. Muitas vezes se inventa uma nova palavra desnecessariamente, como "O autor usou o termo sarcóide para descrever lesões de pele biopsiadas...". O verbo biopsiar não existe; por que não dizer “...lesões de pele submetidas a biópsia"? O mesmo se diga de "cicloplegiar" e tantos outros neologismos desnecessários. O idioma informatês é o campeão dessas barbaridades.

No sentido de... Não se usa mais, no Brasil, a preposição "para". Foi substituída por "no sentido de". Antes se dizia: "Darei uma aula para ensinar estrabismo aos alunos". Hoje, diz-se: "Darei uma aula no sentido de ensinar estrabismo aos alunos". Antes se dizia: "Faremos uma campanha para erradicar a catarata em São Paulo"; hoje, diz-se "Faremos uma campanha no sentido de erradicar a catarata em São Paulo”. Poderíamos ainda dizer, corretamente, "Faremos uma campanha com a finalidade de (ou com o intuito de) erradicar a catarata...". Ridículo! Isso é mais um exemplo de pseudo-erudição.

O mesmo. Esta é uma expressão errada, mas lamentavelmente muito disseminada. Quem a utiliza crê estar falando eruditamente - mal sabe que está cometendo um erro grosseiro. Mesmo é um pronome adjetivo e exige, por isso, a presença do substantivo que está sendo qualificado: "Ambos estão infectados com a mesma bactéria ". Da maneira como se está usando ultimamente ("Devemos estudar português e as matérias que têm relação com o mesmo"; "Este remédio provoca efeitos colaterais; é preciso evitar o uso do mesmo"), o termo seria um pronome substantivo (no exemplo, usado em lugar de "português" e de "Este remédio"), o que é um erro. Por que não dizer: "Devemos estudar português e as matérias que com ele têm relação" e "Este remédio provoca efeitos colaterais; é preciso evitar o seu uso"? Esse erro ridículo tem sido visto em discursos de pessoas consideradas cultas (e que deveriam ser cultas, em vista da posição que ocupam na sociedade!). Justiça seja feita aos americanos; nunca os ouvi dizer "This drug causes collateral effects; the use of the same must be avoided". 
Onde. Este termo é advérbio interrogativo, que se relaciona com lugar (“Onde está a lesão?", o mesmo que "Em que lugar está a lesão?") ou um pronome relativo, que significa "lugar em que" ("A estrutura onde se encontra a lesão...", correspondente a "A estrutura, lugar em que se encontra a lesão..." ou simplesmente "A estrutura em que se encontra a lesão..."). Atualmente se está utilizando com muita freqüência o termo onde como pronome relativo, porém sem conotação de lugar ("Fiz um trabalho onde ficou demonstrado que o oblíquo inferior é elevador do olho"). Nesse caso, deve-se usar o pronome relativo "que" ("Fiz um trabalho em que ficou demonstrado...”). Vale, aqui, uma observação sobre a confusão que às vezes se faz entre onde e aonde. Onde tem conotação estática ("onde está o seu filho?") e aonde, de movimento ("Aonde vai o seu filho?", o mesmo que "Para que lugar vai $\mathrm{o}$ seu filho?")

O óculos. Tive o desprazer, há dias, de ver escrita, num trabalho científico, essa barbaridade. Óculos é plural; referese a um instrumento composto por duas lentes, uma para cada olho. Cada lente constitui um óculo. Deve-se, portanto, sempre referir-se aos óculos (Os seus óculos estão sujos, receiteilhe óculos escuros).

Ótico e óptico. Ótico vem do grego otikós (relativo ou pertencente ao ouvido) e, óptico, do grego optikós (parte da física que estuda os fenômenos da visão e da luz). Há tendência a utilizar-se o termo ótico em relação aos fenômenos refrativos dos olhos; o verbete ótico já pode ser encontrado em dicionários como sinônimo de óptico. Entretanto, como tenho dito insistentemente, a linguagem científica deve primar pela exatidão; pergunto, então, por que provocar essa confusão de significados, somente pela preguiça de escrever ou pronunciar um $\mathrm{p}$ ? Estendase esses comentários a ortóptica, pleóptica, entóptico etc.

Outra alternativa. Alter, em latim, significa outro. Só por isso já se pode perceber que outra alternativa constitui redundância. Portanto, diga-se tão somente alternativa (A melhor alternativa ao tratamento da AIDS é a sua prevenção). Por outro lado, a palavra alternativa subentende que haja pelo menos duas coisas, portanto, é errôneo dizer "A única alternativa para vencer a crise econômica é aumentar as exportações”. Ora, se há alternativa, subentende-se que haja outra opção além do aumento da exportação; uma alternativa jamais pode ser única. Neste exemplo, há diversas palavras que podem ser empregadas, como saída, recurso, procedimento etc.

Papila óptica. A palavra papila dá idéia de saliência; antigamente dizia-se papila do nervo óptico porque se pensava, dada a precariedade dos métodos de observação, que essa estrutura fosse elevada. Hoje, sabe-se que isso não é verdade; aliás, a Nomina Anatomica denomina-a disco do nervo óptico. Aceito que se diga, para simplificar, disco óptico, mas papila óptica é expressão que deve ser eliminada do vocabulário.
Passar em lugar de prescrever. É um erro tão primário, tão absurdo, que não merece comentário. Palavra utilizada pelos pacientes da Sta. Casa (passar um colírio, passar um óculos), com seu característico baixo nível cultural. Podemos perdoar aquele paciente que conta ao seu amigo: "Sinti uma dô nu zóio, fui na Santa Casa, o dotô me passô um corílio e fiquei logo bão". Vindo de um médico, é imperdoável.

Parágrafo. É coisa muito importante saber separar o texto em parágrafos. Uma correta separação de parágrafos facilita a compreensão do texto. O parágrafo é composto por um período (período é uma oração ou um conjunto de orações que formam sentido completo) ou um conjunto de períodos que encerram um pensamento. O parágrafo tem início, meio e fim. Dois parágrafos encerram pensamentos diferentes. Tenho visto textos em que os períodos são separados como se fossem parágrafos - o texto fica todo entrecortado. Vejo, também, parágrafos enormes, às vezes ocupando uma página inteira, incluindo diversos pensamentos completos, independentes entre si. O texto fica de difícil leitura e compreensão. Não há regra rígida para a construção dos parágrafos; o bom senso deve imperar, tendo em vista as considerações acima.

Patologia. Tornou-se hábito, desde há algum tempo, substituir as palavras doença ou afecção por patologia. O ignorante em questões vernáculas crê que, falando patologia para designar doença, está sendo erudito - ridículo! O mesmo seja dito sobre sintomatologia, tecnologia e metodologia. "Tal paciente apresenta rica sintomatologia", "No preparo desse medicamento, utilizou-se tecnologia moderna" e "Fulano empregou metodologia adequada na realização desse trabalho". $\mathrm{Na}$ realidade, o paciente apresenta riqueza de sintomas, no preparo do medicamento empregou-se técnica moderna e Fulano empregou método adequado.

Período compreendido entre 1990 a 1995. Erro semelhante seria dizer "Esta mesa está entre mim $a$ você". Infelizmente, tenho observado esse erro primário com certa freqüência nos trabalhos científicos, embora isso pareça impossível. Diga-se "Período compreendido entre 1990 e 1995". Não se confunda com a expressão "Os fatos ocorreram de 1990 a 1995”.

Phtisis bulbi. Como disse antes, o latim é difícil e pouca gente o conhece. Quem se mete a escrever em latim arrisca-se a errar, e erra com freqüência. O melhor é escrever em português. Diga atrofia bulbar e não se arriscará a errar.

Posição de cabeça. Muitas vezes tenho ouvido colegas dizerem que tal paciente apresenta "posição de cabeça". Na verdade, nunca vi uma pessoa que não apresente alguma posição de cabeça. Esta pode ser normal ou anômala, erecta ou inclinada, neste caso chamada torcicolo. A causa dessa impropriedade lingüística reside no fato de que alguém, certa vez, cometeu-a perante uma platéia e todos os que sofrem de 
preguiça, que infelizmente são muito numerosos, passaram a imitá-lo, sem pensar no que estão dizendo.

Pré-requisito. Antigamente dizia-se (corretamente) requisito. Hoje, não sei porque, inventou-se a moda de dizer prérequisito, o que me parece uma bobagem. Antenor Nascentes define o vocábulo requisito como: "Condição que deve ser satisfeita; exigência legal ou particular, sem a qual um negócio não pode ter andamento". Se o negócio não pode ter andamento sem que a tal exigência seja satisfeita, é evidente que esta precisa ser cumprida antes (pré) do início do negócio. Portanto, o prefixo pré é dispensável; aliás, não se encontra em dicionário a forma pré-requisito.

Ptose. É comum colegas dizerem ou escreverem, até mesmo em teses, que tal paciente apresenta ptose. Isto demonstra imperdoável preguiça. Ptose significa queda, e eu pergunto, queda de quê? Do rim (nefroptose), do testículo (orquioptose)? Na maioria das vezes o colega quer dizer blefaroptose; porque omitir o radical bléfaro?

Quando de. Esta é uma construção que não existe em português, embora possa parecer elegante ao inculto. (Houve muitos discursos quando da inauguração deste auditório). Evitese essa impropriedade dizendo "Houve muitos discursos por ocasião da (ou durante a) inauguração deste auditório".

Refração. Em linguagem coloquial (jargão de ambulatório), diz-se freqüentemente "Vou fazer a refração desse paciente", ou mesmo "Vou fazer refração nesse paciente". Não se admite, contudo, num trabalho científico, que se diga tal impropriedade. O que $f a z$ a refração é a natureza; o médico pode, quando muito, examinar o estado refrativo do paciente, medir o vício de refração ou, mais adequadamente, fazer a refratometria. Também se pode dizer optometria, embora menos apropriado.

Retiniano. Vale o mesmo comentário que fiz para corneano e iridiano. Diga-se retínico.

Se comparado. Quantas vezes tenho lido, em trabalhos oftalmológicos, este erro, cometido simplesmente por não pensar no que se está dizendo, usando fórmulas tradicionais erradas. Aliás, em ciência, o fato de considerar tudo que é antigo como coisa certa, sem parar para pensar, leva freqüentemente a erro. Diz-se: "As lesões corneais foram muito freqüentes, se comparadas com o grupo controle". Pergunto: e se elas não fossem comparadas com o grupo controle, não seriam muito freqüentes? Pensando um pouco sobre a construção dessa frase, vê-se que ela estaria melhor se dissesse: "As lesões corneais foram muito freqüentes, em comparação ao grupo controle", eliminando-se o condicional se.

Seja ou é, esteja ou está? O modo subjuntivo dos verbos é também chamado "modo da possibilidade". Ele é utilizado, entre outros casos, para fatos duvidosos ou indeterminados. Os seguintes exemplos esclarecem a questão: "Fulano afirma que a retina está normal" e "Ciclano supõe que a retina esteja normal". No segundo caso, o autor deixa dúvida; Ciclano não tem certeza do que diz. Esta questão apresenta-se com muita freqüência nas redações científicas.

Seje. O presente do subjuntivo do verbo ser é: seja, sejas, seja.... Não entendo por que algumas pessoas (muitas, infelizmente) dizem seje para a primeira e a terceira pessoas!!! Eu só desculparia esse erro se cometido pelo meu neto de três anos de idade; depois disso, torna-se imperdoável.

Somatória. Errado; diga-se somatório.

Ter $\mathbf{x}$ haver. Erro tão disseminado que, infelizmente, parece estar irremediavelmente introduzido no idioma. O verbo ter dá idéia de posse (Eu tenho [possuo] um automóvel) e o verbo haver significa existir (Há [existe] um automóvel na rua). Há arraigadíssima tendência a confundir o significado do verbo ter, confundindo-o com haver. Assim, diz-se a três por dois: "Tem gente que pensa assim", em lugar de "Há gente que pensa assim". Creio ser fácil distinguir a diferença entre ter e haver nas seguintes frases: "O paciente tem uma lesão na córnea" e "Há uma lesão na córnea do paciente". Pode-se dizer, sem alterar o sentido: "O paciente possui uma lesão na córnea" e "Existe uma lesão na córnea do paciente".

Trauma e traumatismo. É um privilégio para nós, oftalmologistas, poder contar com a presença do Dr. Cássio Galvão Monteiro entre nós. Seria um crime deixar de aproveitá-la em benefício do bom português. Ensinou-nos ele, entre mil outras coisas úteis, um pormenor lingüístico médico muito útil na prática: traumatismo é o ato de provocar um ferimento e trau$m a$ é a sua conseqüência, a lesão causada por ele. A paulada na cabeça é o traumatismo e a conseqüente fratura é o trauma. O sufixo ismo significa ação, portanto traumatismo é a ação de traumatizar. É comum a expressão "Fulano tem trauma de avião"; é uma maneira popular de dizer que Fulano tem medo de andar de avião, por ter sofrido um traumatismo emocional; possivelmente viu um avião cair ou coisa semelhante.

Tropia e foria. Com muita freqüência tenho visto e ouvido, em trabalhos sobre estrabismo, as palavras tropia e foria. Diz-se, por exemplo, que fulano estava em tropia ou que outro apresenta foria. Essas palavras não significam nada. Se Fulano está em tropia, como dizem, pode estar em ortotropia ou em heterotropia e, neste caso, em esotropia, exotropia, hipertropia ou ciclotropia. O mesmo se diga da foria: ortoforia ou heteroforia. Portanto, dizer-se apenas tropia ou foria parece-me expressão de preguiça, injustificável em ciência, que exige precisão de termos. 
Um, uma. Alguns trabalhos mostram verdadeira torrente dos indefinidos um e uma. Isso traz grande deselegância ao texto. Dizia o saudoso mestre Napoleão Mendes de Almeida que "um, um, um" é linguagem suína. Sempre que escrever um ou uma, experimente eliminá-lo e veja se o sentido da frase ficou prejudicado. Na maioria das vezes não ficou e acrescentou-se elegância à oração. Posso citar centenas de exemplos: "Falou com uma voz lenta e solene"; "Manifestou-se com uma certa seriedade"; "Repassadas de um certo e justificado otimismo"; "O governo enfrenta uma grave crise". Experimente suprimir esses uns e veja se houve prejuízo ao sentido das frases e se não se acrescentou elegância. Não digo que nunca se use os indefinidos; muitas vezes eles são necessários, até mesmo por questão eufônica.

Vírgula. Um dos requisitos para a boa redação do trabalho científico é tornar a leitura, por diversos meios, de fácil compreensão, agradável. O leitor tem de esforçar-se para entender o assunto, muitas vezes complexo; é preciso que se lhe facilite a compreensão da linguagem. A vírgula é um dos fatores que amenizam a leitura. Se escrevêssemos sem ela, teríamos de voltar freqüentemente ao início dos períodos para poder entendê-los. E às vezes não os entenderíamos ou entenderíamos algo diferente do que o autor deseja dizer. Vejam-se estes exemplos: "Não opere já este paciente" ou "Não, opere já este paciente"; "Jamais colem nas provas" ou "Jamais, colem nas provas". Infelizmente, vejo um desconhecimento quase total das regras de colocação de vírgulas entre a esmagadora maioria dos colegas. Com muita freqüência, parece que estes escrevem uma página sem nenhuma vírgula e, ao fim, pegam um macinho de vírgulas de uma caixinha ao lado e espargem-nas sobre o texto; onde caírem, aí ficam.

São muitas as regras para a colocação da vírgula, mas o bom senso pode substituir o conhecimento de muitas delas, desde que se saiba para que serve a vírgula e que se conheçam algumas regras principais. É claro que se deve ter algum conhecimento de sintaxe; jamais escreverá corretamente quem desconhece o que vem a ser sujeito, predicado, objeto direto ou indireto, adjunto adnominal ou adverbial etc.. De modo geral, pode-se dizer que a vírgula indica pequena pausa. Mas a recíproca nem sempre é verdadeira. Em linguagem falada, às vezes, por mera questão de ênfase, separa-se o sujeito do seu verbo por breve pausa, ou o verbo do seu complemento, ao passo que graficamente isso constitui grave erro; não se separam por vírgula palavras que mantêm entre si estreita relação sintática. Quantas e quantas vezes tenho visto sujeitos separados dos seus verbos por vírgula, como: "O residente, faltou à aula por estar enfermo". Em grande número de casos, as vírgulas exercem papel de parênteses. Aberto o parêntese, é claro que o devemos depois fechar. "O paciente (após despertar da anestesia) sentiu-se bem"; o mesmo que "O paciente, após despertar da anestesia, sentiu-se bem". Desta forma, se retirarmos a locução que está entre as vírgulas, surgirão ligados os termos essenciais da oração, ou os que têm entre si estreita ligação sintática: "O paciente sentiu-se bem”. A oração não perdeu sentido. Uma das regras mais importantes de colocação de vírgulas é a que se aplica a esse caso: duas vírgulas ou nenhuma. O lugar onde colocar a primeira delas também tem sido confundido por muitos; lembre-se de que elas separam uma locução que pode ser retirada da oração, sem que esta perca sentido. Veja-se o exemplo: "O aluno, que por desconhecimento, chegou atrasado, perdeu a prova". Se retirarmos o que está entre vírgulas, a oração fica truncada: "O aluno chegou atrasado, perdeu a prova". O autor quis dizer: "O aluno que chegou atrasado perdeu a prova". Portanto, esse pronome relativo que deve vir antes da vírgula, pois não faz parte do adjunto adverbial "por desconhecimento". Escreva-se, então: "O aluno que, por desconhecimento, chegou atrasado, perdeu a prova". Não estaria errado escrever "O aluno, que por desconhecimento chegou atrasado, perdeu a prova"; o que está entre as vírgulas equivale a um aposto que, se eliminado, não prejudica o sentido da oração - "O aluno perdeu a prova".

Citemos algumas das regras para emprego de vírgulas; somente as mais freqüentemente aplicadas na redação científica.

1. Emprega-se vírgula entre vários sujeitos de um mesmo verbo: "Virus, bactérias, fungos e Rickettsias constituem os elementos etiológicos das infecções". Também separa diversos complementos de um mesmo verbo: "A lavagem das mãos elimina sujeira, bactérias, esporos e vírus". Note-se que, entre o penúltimo e o último elemento, substituí as vírgulas pela conjunção aditiva $e$. Isso não é obrigatório, mas creio ser mais adequado para a linguagem científica. Poderia ter colocado também a conjunção alternativa $o u$. Note-se que a conjunção substitui a vírgula, não se soma a ela. Vale lembrar, aqui, que é ilógico usar vírgula antes do etc., pois este significa " $e$ outras coisas" (já consta o $e$ ). Ninguém escreveria "Maçãs, pêras, $\mathbf{e}$ outras coisas". Infelizmente o erro está consagrado pelo uso (ainda considero melhor não usá-la). A não substituição da vírgula pela conjunção e entre os dois últimos elementos do sujeito ou do complemento composto indica que, além dos elementos citados, existem outros - "A lavagem das mãos elimina sujeira, bactérias, esporos, vírus". É como se houvesse um etc. após a palavra vírus. O trabalho científico não admite tal forma.

2. Às vezes, a vírgula é utilizada para dar ênfase a certas locuções: "O médico empregou, e o caso exigia, toda a sua capacidade.

3. No aposto. Aposto é o substantivo ou a locução substantiva que explica ou esclarece outro substantivo. $\mathbf{O}$ aposto deve vir entre vírgulas. Ex.: "O glaucoma, essa moléstia traiçoeira, é importante causa de cegueira"; "Os pacientes da Santa Casa, sempre de baixo nível sócio-econômico e cultural, apresentam características patológicas diferentes do cliente particular".

4. Nos adjuntos adverbiais. Adjunto adverbial é um advérbio, ou uma expressão adverbial, que indica uma circunstância de tempo, lugar, modo etc. (modificando o verbo). "O glaucoma não tratado, com o passar do tempo, leva à cegueira"; "O 
glaucoma não tratado, lentamente, acaba levando à cegueira"; "O glaucoma, no Brasil, é importante causa de cegueira". Quando o adjunto adverbial vem no início da oração, deve vir separado por vírgula: "Com freqüência, o glaucoma tem levado pessoas à cegueira neste país”. Esta regra não é absoluta; a vírgula é usada para dar ênfase ao adjunto adverbial ou para evitar má interpretação. Pode-se dizer "O glaucoma no Brasil é importante causa de cegueira" (sem vírgulas), mas o mesmo não ocorre com a oração "O glaucoma não tratado lentamente acaba levando à cegueira". Neste caso, pode-se entender que o advérbio lentamente refere-se ao verbo tratar e não, como quer dizer o autor, ao verbo levar, e o significado da oração é gravemente alterado.

5. Para isolar certas palavras e expressões explicativas, corretivas, continuativas ou conclusivas, tais como: por exemplo, além disso, isto é, a saber, aliás, digo, ou melhor, outrossim, então etc. (neste caso a vírgula é obrigatória). "O glaucoma, isto é, a hipertensão intra-ocular pode levar à cegueira”; "Há diversos remédios para o glaucoma, a saber, a pilocarpina, os beta-bloqueadores, os inibidores da anidrase carbônica etc."; "O estrabismo, além disso, causa problemas emocionais". Sempre duas vírgulas!

6. Para isolar as conjunções adversativas porém, contudo, todavia, entretanto e no entanto e as conjunções conclusivas logo, pois, portanto quando estão no meio da oração ou, principalmente, quando a iniciam: "O glaucoma é grave, entretanto, pode ser curado". "Contudo, seu tratamento não é difícil"; "Você é ainda R1, $\log o$, ainda não pode operar catarata".

7. Para separar as orações subordinadas adverbiais e as coordenadas: "A dor era tanta, que o paciente chegou a desmaiar"; "Como está melhorando, continuemos com o mesmo remédio"; "Se houver infecção, aplique-se um antibiótico"; "Não corra, não mate, não morra"; "Não é um aleijado mental, mas comete erros imperdoáveis".

8. Para indicar supressão do verbo (zeugma). "Os R2 operam de tudo, enquanto os R1, só pterígio” (...enquanto os R1 só operam pterígio).

Ponto e vírgula. $\mathrm{O}$ ponto e vírgula tem mais força que a vírgula e menos que o ponto final. Ele é usado para:

1) Separar orações absolutas que têm certa extensão, sobretudo se elas possuem partes já divididas por vírgulas: "Antigamente, o antibiótico mais utilizado era o cloranfenicol; hoje, prefere-se usar a penicilina e os seus derivados". "É interessante o fato de que, nas reuniões, os residentes sen- tam-se no fundo da sala; os assistentes, geralmente, preferem sentar-se à frente". Tenho visto, com freqüência, colegas usarem ponto e vírgula em lugar de virgula, em separação de simples palavras.

2) Separar as partes principais de uma frase, cujas partes subalternas são separadas por vírgulas: "Paulo, Roberto e Sílvia são R1; Alberto, Maria e Sônia, R2; Cecília e Antônio, R3". Note que, nas duas últimas partes, o verbo ser (são) está substituído por vírgula (zeugma).

Dois pontos. Tenho visto, freqüentemente, os dois pontos utilizados de forma errada. O seu emprego é, entretanto, muito simples:

1) Para anunciar uma citação: "Aristóteles dizia a seus discípulos: "Meus amigos, não há amigos"; "Os estrabólogos sempre afirmam: a ambliopia deve ser tratada precocemente".

2) Para indicar uma enunciação ou uma enumeração: “Os meios legítimos de obter sucesso profissional são três: estudo, trabalho e ética"; "Os três antibióticos mais utilizados atualmente são: a penicilina, o cloranfenicol e a tetraciclina".

Visualizar. A língua portuguesa é muito rica. Geralmente sobejam palavras para expressar alguma coisa, muitas vezes introduzindo sutis diferenças. Quantas vezes tenho ouvido ou lido frases como "Foi difícil visualizar a retina porque o vítreo estava turvo". Visualizar significa "ver com a imaginação", "imaginar". Garanto que sou capaz de visualizar perfeitamente, de olhos fechados, a retina de um olho portador de catarata madura. Por que desvirtuar o significado de palavra tão útil? Quando quisermos usar o termo visualizar, com o seu significado correto, já não mais o teremos disponível, pois estará, por força do mau uso, significando outra coisa. O português conta com várias palavras, com sutis diferenças semânticas entre elas, para utilizar-se nessa frase: ver, enxergar, vislumbrar, entrever, lobrigar, avistar, discernir e distinguir. Com toda essa riqueza, por que escolher um termo errado? Será porque o ignorante crê ser mais elegante dizer visualizar, tal como ocorre com patologia, metodologia, tecnologia e sintomatologia? O mesmo se diga quanto ao substantivo "visualização", utilizado em lugar do termo correto "visibilidade", como em "A má visualização (visibilidade) do fundo de olho impossibilitou um diagnóstico correto ". Os americanos também erram, dizendo visualize; os seus dicionários conferem o mesmo significado ao termo que em português.

\section{Novidades na Internet!:!}

Agora no site CBO você tem disponível todas as informações na íntegra dos

Arquivos Brasileiros de Oitalmologia

httpa//w w w.cbo.com.br/abo 